\title{
An Analysis of Dispute Resolution Mechanisms in the Islamic Banking and Finance Industry in Malaysia
}

\author{
Aishat Zubair ${ }^{1}$ \\ ${ }^{1}$ Faculty of Law, Kwara State University Malete, Nigeria \\ ayyesha@gmail.com
}

\begin{abstract}
Introduction to The Problem: With the increasing boost to the Malaysian Islamic finance industry and the sophistication experienced in the industry with regards to product development, there is a substantial downside of such enviable achievements, which is the gradual surge in the number of disputes involving Sharia-compliant transactions. It is therefore important to analyse the existing dispute resolution mechanisms in the Islamic finance industry in Malaysia.

Purpose/Objective Study: The article aims to analyse the court system as a dispute resolution mechanism as well as the other alternative dispute resolution mechanisms available to parties in resolving the dispute in the Islamic banking and finance industry in Malaysia.

Design/Methodology/Approach: This study adopts a doctrinal legal method in examining the relevant Islamic dispute resolution mechanisms that are unique to Islamic finance disputes.

Findings: The findings of this research reveal that some issues are causing untold hardships on parties in Islamic finance contractual disputes with the present jurisdiction of the courts in Malaysia. It is in line with the hypothesis of the research that the continued preference for litigation as a means of settling disputes in the Islamic finance industry is not sustainable due to the paradigm shift in dispute resolution involving financial matters globally.
\end{abstract}

Paper Type: Research Article

Keywords: Dispute Resolution; Malaysia; Court System; Arbitration; Mediation

\section{Introduction}

The attribute of Islamic values forms part of the strong foundation of the Islamic finance industry. The various rules and regulations governing contractual transactions which are based on justice and honesty and which are meant to safeguard the parties' interests in the transaction against any frustration and noncompliance are expected to be present in any Islamic finance contract. This regulation is very important as one of the aims of formulating a financial system by Islamic law is to protect the poor and the weak, while at the same time providing a venue for the creation of fair and just profits to the capital suppliers. It is even truer when the concept of wealth in Islam as a trust (amānah) from Allah for which everyone is going to be accountable for is understood. 
However, the Islamic finance industry in Malaysia may be said to be presently dispute ridden. An important reason for the incessant occurrence of disputes from Islamic finance contracts is that most of the contracts are now being modified and expanded through the use of ijtihad (it is the use of deductive reasoning to arrive at Islamic rulings that are not explicitly provided for in the primary sources of the Shari'ah) by the Islamic banks, thereby making them even more sophisticated. As David Leibowitz and Claire Lester put it "...the variety and complexity of disputes have grown as the banks and financial institutions, have provided an increasingly wide variety of products and services to customers" (Leibowitz \& Lester, 2002). Thus, there has been a proportionate increase in the volume of associated complaints from the general public over the past few years because of the rapid expansion of products and services particularly in the field of consumer credit. Another possible explanation for the increase in dispute in the industry has been said to be that "customers have become increasingly sophisticated and are increasingly prepared to exercise their rights against nationals or multinationals" (Leibowitz \& Lester, 2002). Everyone now wants to run to court even with the smallest claim just to prove his right. It is evident in the nature of Islamic finance cases finding their way into the court's system, particularly in the civil courts of Malaysia.

This article is divided into four sections, beginning with the introduction. The second section analysed the court system as a dispute resolution mechanism for the Islamic banking and finance industry in Malaysia, showing the numerous challenges faced by parties in the process. The third section analysed the other alternative dispute resolution mechanisms provided by various institutions in Malaysia in the Islamic banking and finance industry and lastly is the concluding section where recommendations are given to surmount the challenges identified.

\section{Methodology}

In prosecuting the study, doctrinal legal research is well-suited. This research design is quiet imperative and handy to examine the existing dispute resolution mechanism in the Islamic banking and finance industry in Malaysia to identify the legal issues that are appalling to its use by parties in resolving disputes involving Shari'ah-compliant transactions. The rationale for choosing this design is to allow synthesis and reconcile the various viewpoints on the phenomenon of study to produce results of lasting value and effect. The analytical tool used is the legal content analysis tool.

The legal content analysis tool is used to analyse the court system as one of the most important dispute resolution mechanisms used in the Islamic Banking and finance industry in Malaysia. This analytical tool has proved useful in this regard as the relevant section of the constitution, i.e. Article 121 of the Federal Constitution is analysed to ascertain the present jurisdiction granted to the courts in Malaysia to adjudicate on Islamic banking and finance matters. This analytical tool is further used to analyse some Malaysian courts decisions in cases involving Shari'ah-compliant transactions. This step is to show that jurisdiction over Islamic banking and finance 
matters rests with the civil courts that are manned by judges who are unqualified to sit over Islamic banking cases and has brought untold hardship on parties involved. The application of the doctrinal legal method, therefore, becomes imminent in examining the other alternatives available to parties in the Islamic banking and finance industry in Malaysia which includes Arbitration, Mediation and Ombudsman to ascertain whether or not they can conveniently fill the gap created by the court system or not.

\section{Results and Discussion}

\section{Court System as a Mechanism for the Resolution of Islamic Banking and Finance Disputes}

The civil courts in Malaysia use the dispute resolution mechanism in resolving Islamic finance disputes that are brought before its judges. The earlier position in Malaysia was that the Sharīah courts and civil courts exercised concurrent jurisdiction on some issues involving Islamic law. The Federal Constitution sets out the jurisdiction of the courts under Article 121 of the Federal Constitution, and it states that:

Article 121 "(1) There shall be two High Courts of co-ordinate jurisdiction and status, ... and such inferior courts as may be provided by Federal law; and the High Courts and inferior courts shall have jurisdiction and powers as may be conferred by or under Federal law."

Thus the jurisdiction of the civil courts includes all matters conferred by the Federal and State law except for the personal law of Muslims. List 1 of the $9^{\text {th }}$ schedule of the Federal Constitution, known as the Federal List contains civil and criminal procedure and administration of justice. The relevant part in List 1 is Item 7: Finance including (j) banking (K) bills of exchange, promissory notes and other negotiable instruments (l) foreign exchange; Item 8: Trade, commerce and industry including: (c) incorporation, registration and winding up of company (d) insurance.

Even though Islamic law matters are state issues, but according to the Federal Constitution according to Section 1 of the Second List in the Ninth Schedule, it provides that the Sharīah court has no exclusive jurisdiction on all Islamic matters for example Islamic finance. The Malaysian Supreme Court decision further reinstated this in Mamat bin Daud v. Government of Malaysia [1988] 1 MLJ 119 (SC)] where the apex court held in its majority decision that only the State Legislature will have the exclusive powers to enact laws on Islamic matters. Furthermore, the $9^{\text {th }}$ schedule of the Federal Constitution also provides the Sharī'ah court's jurisdiction under its Para 1 List II. This provision excludes the jurisdiction of the Sharīah court on finance matters as it falls under federal matters.

The jurisdictions of these two courts seem to overlap in some instances, where the civil courts entertain matters that are supposed to be within the purview of the Sharīah courts. There were some limitations to the exercise of exclusive jurisdiction by the Sharīah Court, for example on matters involving parties being a Muslim and a 
Non-Muslim. This condition is further exacerbated by the fact that civil court has the power of review over the Shari'ah Courts and have been seen in some cases to have exercised this by overturning the decisions of the Sharīah Courts upon appeal to its court by one of the parties. Therefore, there were lots of criticisms that necessitated an amendment to the Federal Constitution in 1998. It brought about the inclusion of clause $1 \mathrm{~A}$ in Article 121 of the Federal Constitution which states that "The Courts referred to in clause (1) shall have no jurisdiction in respect of any matter within the jurisdiction of the Syariah courts." With this amendment, therefore, the civil courts are refrained from adjudicating cases in which Islamic law is applicable and such jurisdiction is now vested in the Sharīah courts exclusively. Civil courts, therefore, no longer have jurisdiction over matters that fall within the purview of the Shari'ah courts and the power to review Shari' $a h$ courts' decisions has been taken away by this provision. Because the clause was introduced to put to rest the confusion in case law on the actual demarcation of civil courts' jurisdiction and Sharī'ah courts' jurisdiction, it was presumably expected to settle the issue and prevent further conflict of the jurisdiction (Bustami et al., 2010).

However, this is not to be the case because of some reasons. First, although the term 'Islamic law' in para 1, List II of the $9^{\text {th }}$ schedule is wide, its application is limited to persons professing the religion of Islam (Halim, 2011). This provision does not mean that if both parties to an Islamic finance transaction are Muslims, the matter can fall under the Shari'ah jurisdiction. The judgement of the Supreme Court in the case of Mohamed Habibullah bin Mohammed v Faridah Dato Talib [1992] 2 MLJ 793 which ruled that Sharīah court can only decide matters are falling under its jurisdiction is instructive here. The Judge, Harun Hashim S.C.J reasoned that in the absence of express provisions, it is not sufficient merely to show that both parties are Muslims if the matter at hand does not fall under the jurisdiction of the Shari'ah courts (Hamzah \& Bulan, 2003). This restrictive approach adopted by the Supreme Court, in that case, appears to be the accepted interpretation of the phrase 'within the jurisdiction' in Clause $1 \mathrm{~A}$ of Article 121, the basis of which has been explained by the judge thus:

"Taking an objective view of the Constitution, it is obvious from the very beginning that the makers of the Constitution clearly intended that the Muslims in this country shall be governed by the Islamic family law as evident from the $9^{\text {th }}$ Schedule to the Constitution ... What Article $121(1 \mathrm{~A})$ has done is to grant exclusive jurisdiction to the Sharīah courts in the administration of such Islamic laws. In order words, Article $121(1 \mathrm{~A})$ is a provision to prevent conflicting jurisdiction between the Civil Courts and the Shari’ah Courts."

Thus, the clause has no general application to legal persons, such as banks and financial institutions, which cannot be construed to be professing the religion of Islam (Yaacob, 2012).

Secondly, there is only Federal legislation on Islamic Banking and Finance (IBF). Since the Sharīah courts are state courts and have jurisdiction only within the respective states, it is necessary to have provisions relating to Islamic finance in the state 
legislature before it can come under the jurisdiction of the Sharī'ah courts (Ibrahim \& Joned, 1995). Although Islamic law falls under the state list, this does not automatically confer the jurisdiction over Islamic finance matters on the Sharīah courts. The state legislatures must thus first act upon powers given to it by the Federal Constitution, i.e. according to Article 74 and 77 and accordingly enact laws conferring the jurisdiction on the Sharīah courts by incorporating the appropriate provisions to that effect. It is clear from the discussions so far that civil courts will not have jurisdiction over matters upon which Sharīah courts have jurisdiction. Therefore, going by this analysis, the jurisdiction to hear Islamic finance cases lies with the civil courts.

Thirdly and most importantly is that banking and finance come within of List I of the $9^{\text {th }}$ schedule. As such, the amendment to Article 121 of the Constitution does not take away the jurisdiction of the High Court in matters that are in the Federal List. Such matters include banking and finance. In the case of Dato' Nik Hj Mahmud Bin Daud v Bank Islam Malaysia Bhd [1996] 4 MLJ 295, the Defendant argued that since BIMB (plaintiff) is an Islamic bank, the Civil Court had no jurisdiction to hear the case because of Article 121 (1A) of the Federal Constitution 1957. The judge, N.H. Chan, overruling this objection submitted that the matter was rightly brought before the civil court. It was further held that BIMB being a corporate body has no religion and therefore does not fall within the jurisdiction of the Sharĩah Court.

I cannot, therefore help but agree more with the conclusion of an expert in the field in these words:

"Based on the provisions in the FC [Federal Constitution] above, it can be concluded that the jurisdiction over Islamic banking and finance matters rests with the civil courts. This is due to the fact that banking and finance matters are within List I (Federal List) of the 9th Schedule on mercantile law. Although the term 'Islamic law' in Para 1, List II of Ninth Schedule is wide, its application is llimited to persons professing the religion of Islam. Thus, it has no general application to other persons and legal persons, such as banks and financial institutions, who cannot be construed to be professing the religion of Islam. Furthermore, the legislations on Islamic banking and finance are all federal legislations that are subject to the civil courts' jurisdiction. There has not been any state legislation on Islamic banking and finance matters" (Ali, 2008).

Several issues are brought to the fore with the present jurisdiction of the courts in Malaysia with regards Islamic finance cases causing untold hardships on the parties in the Islamic finance industry. There is a problematic issue of judges applying civil law to Islamic banking contracts. Civil courts are inclined to decide IBF cases strictly based on civil laws and procedures without considering the Islamic dimension of IBF documents. In Dato' Nik Hj Mahmud Bin Daud v Bank Islam Malaysia Bhd [1996], 4 MLJ 295 the Plaintiff had executed two agreements, namely the 'Property Purchase Agreement' and the 'Property Sale Agreement' with the Defendant. There was a purchase by the Defendant through the former agreement of properties for a price of 
RM520,000.00 which were then resold through the agreement latter to the Plaintiff for RM629,200.00. Both agreements were signed contemporaneously. The Plaintiff's attorney executed two charges of the said lands in favour of the Defendant as securities. The Plaintiff applied for an order that the charges, the Property Purchase Agreement and the Property Sale Agreement be declared null and void and of no effect. The Plaintiff contended that the execution of the Property Purchase Agreement, the Property Sale Agreement and the charge documents would be tantamount to an exercise to defeat the purpose and intention of the Kelantan Malay Reservations Enactment 1930 and the National Land Code (NLC). The Court dismissed the application and held that there was no transfer affected, and the proprietorship remained with the Plaintiff. That the concurrent execution of the Property Purchase Agreement and the Property Sale Agreement constituted part of the process required by the Islamic banking procedure before the Plaintiff could avail himself of the Financial facilities provided by the Defendant under the Bay' Bithamin Ajil concept.

Furthermore, in the case of Bank Islam Malaysia Berhad v Adnan Omar [1994] 3 CLJ 735 where the Plaintiff had provided a financing facility of RM 583,000 to the Defendant under Bay'Bithamin Ajil (BBA), and it was secured upon a charge over a certain parcel of land. A term of the charging document stated that in the event of any default in the payment of the financing instalments by the Defendant, then the Plaintiff would be entitled to sell the land. The issue before the court was whether the Plaintiff had full knowledge of the term and whether the parties were at ad idem when they entered into the contract. The court held that the transactions between the parties were above board and made with the full knowledge of the Defendant who knew that the entire exercise was to implement the grant of financing to him through a transaction within the limits of the Islamic law. His knowledge of this was evidenced by his acceptance of the letter of offer containing all the terms of the financing. This being the case, this court can only accept the Plaintiff's statement of the amount of advance under Order 83 rule 3(3)(a) of the Rules of the High Court 1980 as being RM 583,000 . The amount is in accord with the intention of the parties, and the Defendant cannot now dispute the amount.

There is also the issue of manning of the civil court by judges who are unqualified to sit over Islamic Banking cases. The judgement of Abdul Wahab Patail J in the case of Affin Bank Bhd v Zulkifli bin Abdullah [2006] 3 MLJ 67 where the judge said: If the customer is to pay the profit for the full tenure, he is entitled to have the benefit of the full tenure (Patail, 2007). It follows that it would be inconsistent with his right to the full tenure if he could be denied the tenure and yet be required to pay the bank's profit margin for the full tenure. To allow the bank also to be able to earn for the unexpired tenure of the facility means the bank can earn a profit twice upon the same sum at the same time. The profit margin that continued to be charged on the unexpired part of the tenure cannot be actual profit. It was unearned profit. It contradicted the principle of Bay' Bithamin Ajil as to profit margin that the provider was entitled to. If the profit had not been earned, it was not profit, and should not be claimed under the Bay' 
Bithamin Ajil facility. The profit margin could be calculated and derived with certainty. Even if the tenure was shortened, the profit margin could be recalculated with equal certainty. Suriyadi Halim Omar J (as he then was) in the case of Arab-Malaysian Merchant Bank Bhd v Silver Concept Sdn Bhd [2006] 8 CLJ 9, stated that "...in the event, any litigation is commenced, it must be appreciated that not every presiding judge is a Muslim, and even if so, may not be sufficiently equipped to deal with the matters, which the "Ulama (Jurist) take years to comprehend". Based on these cases, the authors note that: "based on the overall analysis of the Court decisions, particularly in deliberating Sharīah issues, it is observed that the judges in the civil courts to a certain extent do not have the competence to deal with Sharīah matters" (Hasan \& Asutay, 2011).

There is also the issue of the competency of lawyers. Based on the overall observations of the legal defence raised by the lawyers in Islamic finance cases, the Sharīah defence was found to be merely a lawyer's construct. Most of the Sharī'ah issues argued in the Islamic finance disputes were constructed by the lawyers' understanding of the principles of fiqh al-mu'ämalät in which some of them had limited knowledge. Moreover, most of the contractual agreements in Islamic financial contracts are drafted by lawyers that are heavily influenced by the English legal drafting techniques (Bälz, 2004).

Thus, in 2003, there was the provision (Practice Direction No. 1/2003, paragraph 2) for a specialised high court judge to preside over IBF cases at the Muamalat (Commercial) Division of the Kuala Lumpur High Court, so that future courts' decisions will take better cognisance of Islamic legal principles (Miskam \& Hamid, 2011). It was meant to "encourage a sort of expert determination of Islamic finance disputes, albeit through adjudication" (Oseni \& Ahmad, 2015) since Islamic finance disputes fall under the High Court's jurisdiction. Therefore, the Muamalat (Commercial) Division of the High Court has exclusive jurisdiction to decide cases of Islamic finance (Paragraph 2 of the Practice Direction No. 1/2003). The introduction of this bench, though laudable, did not record the success expected as the challenge of adequate access to justice still lingered on. The judge that was placed at the bench to man the court and hear Islamic finance cases, though supposedly with an Islamic background determines most of the cases that were brought before him in an unexpected manner and contrary to the spirit and principle of Islamic finance. He continued to use the conventional banking and principles of common law contract to decide Islamic finance disputes which resulted in some judgement that attracted lots of criticisms from all quarters as they were contradictory to the Shari ${ }^{\top} a h$ principles of IBF in Malaysia. The judge equated the transaction of Bay' Bithamin Ajil (BBA) to a loan transaction where the term 'loan' and 'interest' were frequently used. The judge also applied the equitable principle in interpreting BBA, and he computed daily profit into excellent selling price, thereby converting Sharīah contract to a conventional loan. Therefore, the judge was still applying the common law principle to Islamic 
banking cases, and hence the problem is still not solved. This case is one of the reasons for the need for ADR in the Islamic finance industry.

Also in 2009, The Central Bank of Malaysian Act (CBMA) 2009 which provides for the reference of any question relating to Sharī'ah matters to the Sharī'ah Advisory Council (SAC) was enacted (Sec. 56 of CBMA 2009) (Malaysia, 2013). It was meant to solve the issue of lack of expert in Islamic finance as judges handling the civil courts. However, there have been cases where parties have challenged the authority of the SAC in giving its ruling, claiming that this amounts to usurping the powers of the Court. In the case of Tan Sri Khalid Ibrahim v Bank Islam Malaysia Berhad [2010] 4 CLJ, the Plaintiff challenged the BBA facility agreements and the Defendant, Bank Islam made an application to the High Court to refer to SAC for its ruling on Sharīah questions. The Plaintiff objected on the ground that section 56 and section 57 of CBMA 2009 which provide for reference to SAC were unconstitutional and that the two sections came into effect after the actions were filed and could not apply retrospectively. The High Court held that sections 56 and 57 of CBMA 2009 were procedural and they can have retrospective effect. On the issue of the constitutionality of sections 56 and 57, the High Court held that the function of SAC was confined to the ascertainment of Islamic law on a financial matter and it is still the court's function to apply it to the facts of the case. The Court of Appeal affirmed this in 2012 as it held on the issue of the alleged usurpation of the powers and jurisdiction of the court by the SAC that the duty of SAC is confined exclusively to the ascertainment of the Islamic law on financial matters or business. The judicial function is still vested with the court, i.e. to decide on the issues as pleaded. The court system is, therefore imbued with issues that make resolving Islamic finance disputes challenging (Ali et al., 2014). It necessitated the need for ADR in the Islamic finance industry in Malaysia.

\section{Alternative Dispute Resolution Mechanisms for the Resolution of Islamic Banking and Finance Dispute}

Despite the numerous challenges identified in the last section faced by parties in resolving their disputes through the court system, it seems to be still the most widely known dispute resolution mechanism for the resolution of Islamic banking and finance disputes. According to statistics, the number of cases handled through the court process increased tremendously to about 8702 from the year 2003 to the year 2016 (Dahlan, 2018). The court process could, therefore pass as the only model of dispute resolution in the Islamic banking and finance industry in Malaysia (Ali et al., 2014). This fact, in a way, has made the other alternative Dispute resolution mechanisms provided by various institutions less popular in the Islamic banking and finance industry in Malaysia. It has been shown among other reasons, that cost of resolving Islamic banking disputes using the ADR mechanisms is a weakness, and thus a threat to the continual use of these mechanisms. It has relegated them to the background making their use to still be at a very minimal level despite their numerous strengths and opportunities (Ali et al., 2014). Research shows that there has been a 
recent decline in the number of cases resolved by Arbitration (Dahlan, 2018). Hence an analysis of these mechanisms is most paramount.

\section{Arbitration}

Arbitration is a mechanism of dispute resolution used in the Islamic finance industry where there is the referral of a Dispute to one or more impartial persons for a final and binding determination. Arbitration is a mechanism for resolving Islamic finance disputes in Malaysia is the alternative to the court process that has over the years been the first point of call for parties in the Islamic finance disputes. Its procedure is streamlined to produce a quick, practical, economically efficient settlement alternative to the court process. Disputes under arbitration are resolved by an award made by an independent third party called the arbitrator (this could be one or a tribunal depending on the peculiarity of the case). The arbitrator or tribunal could either be agreed by the parties or nominated by a further independent body, for example, the court or a professional institution such as the Chartered Institute of Arbitrators (Yaacob, 2012).

Malaysia, apart from being considered the financial hub in the world, is gradually emerging as one of the key arbitration hubs in the Asia-Pacific region (Leong \& Mann, 2012). With a constant search for development and progress, Malaysia has emerged as a promising destination in terms of alternative dispute resolution, for parties and arbitrators alike. It is further considered as an arbitration-friendly country. Malaysia, therefore, stands a chance to lead the region when it comes to Islamic finance arbitration.

The main legal framework for arbitration for Islamic Finance disputes in Malaysia is the Malaysian Arbitration Act 2005 that was amended in 2011. Sections 38 and 39 of the Act now provide a uniform process for recognition and enforcement of arbitral awards. Section 38(1) provides thus:

"On an application in writing to the High Court, an award made in respect of a domestic arbitration or an award from a foreign State shall, subject to this section and section 39 be recognised as binding and be enforced by entry as a judgment in terms of the award or by action."

Section 39 provides for the grounds for refusing recognition or enforcement by the High Court. This regulation is significant in the sense that awards made by an arbitration institution can be enforced.

The Accounting and Auditing Organisation for Islamic Financial Institutions (AAOIFI) also released Standard No. 32 on Arbitration for Islamic finance disputes in 2010. Though the Arbitration standard is a mere generally guideline, it gives the institutions providing arbitration services with an idea of how they should approach the procedure to settle favourably to all parties involved. Furthermore, there has been established the Asian International Arbitration Centre (formerly known as KLRCA) which has as its Part I, the AIAC Arbitration Rules which became effective on 9th 
March 2018. The AIAC Arbitration Rules are a set of procedural rules covering all aspects of the arbitration process, which parties may agree to in part or in whole to help resolve their domestic or international disputes. There is in the provision of facilities for arbitration under the Arbitration Rules for settlement of disputes in matters arising out of commercial transactions. Rule 11 of the AIAC Arbitration Rules provides thus:

"The Director shall, at the request of the arbitral tribunal or either party, make available, or arrange for, such facilities and assistance for the conduct of the arbitral proceedings as may be required, including suitable accommodation for sittings of the arbitral tribunal, secretarial assistance, transcription services, video or teleconferencing and interpretation facilities. The costs of such additional facilities shall be borne in equal shares by the Parties unless otherwise agreed by the Parties."

It is imperative to state that parties wishing to submit their disputes to an arbitration institution should have a clause in their agreement similar to the model arbitration clause thus: "Any dispute, controversy or claim arising out of or relating to this contract, or the breach, termination or invalidity thereof shall be settled by arbitration under the AIAC Arbitration Rules."

Also of paramount to the dispute resolution mechanism, arbitration, is the provision of section 56 of CBMA 2009, which makes Malaysia the suitable avenue for arbitration in Islamic finance. It provides for the reference of any question relating to Sharīah matters to the SAC. The CBMA 2009 has clearly stated under its sections 56 and 57 that it is the duty of the court or arbitrator to either take into consideration any published rulings of the SAC for its ruling or advice. And any ruling made according to a reference made under section 56 is binding on the court.

It is pertinent to note that some Islamic finance disputes have been arbitrated successfully in Malaysia under the auspices of the AIAC. One related case that further projected the relevance of arbitration in a dispute involving an Islamic bank and the limited jurisdiction of the civil court is Rmarine Engineering (M) Sdn Bhd v. Bank Islam Malaysia Bhd [2012] 10 MLJ 453. The case involves a contract of guarantee involving the Islamic bank, and there was a default of payment by the principal, which consequently led to an on-demand performance guarantee. The case was referred to arbitration where three learned arbitrators, within nine (9) months, gave a final and binding award. The plaintiff was dissatisfied with the award and argued there was an error on the face of the award. The High court upheld the findings of the arbitral tribunal and held that the court could not intervene as the award was final, binding and conclusive. Upon further appeal to the Court of Appeal in the above case, the appellate court upheld the decision of the High Court.

\section{Court-Annexed Mediation}

It is yet another of the mechanisms used in resolving Islamic finance disputes in Malaysia. Just as the name implies, it is a mediation process that is annexed to the 
court. It is also sometimes called judge-led mediation because a judge sits as the mediator. The judge hearing the case initially before it was referred for mediation may still be the mediator as long as the parties involved agreed to that. Also, the judgeturned-mediator may see the parties in the absence of their lawyers once they consent to it.

The process of court-annexed mediation is different from the existing traditional mediation practices in the cultural heritages of the predominant Malays. The courts in Malaysia then adopted some models which were based on best practices in the UK, Australia and the United States. In 2000, the court-annexed mediation project was introduced in Malaysia in Penang, which was a success (Oseni \& Ahmad, 2015). To increase the adjudication process and to align with advances experienced in other common law jurisdiction, there has been a reform that further allows for court referrals which were through the High Court Rules of 2012.

Before this development, on 16th August 2010, The Chief Justice of Malaysia issued the Practice Direction No. 5 of 2010 and was seen as a welcome development in the civil justice system in Malaysia. This development is known as the Practice Direction on Mediation (Yiam, 2009). It directed and mandated all judges to first refer all cases to mediation before proceeding to trial by adjudication. It is said that "in order to encourage expert determination of Islamic finance disputes through amicable means, this Practice Direction on Mediation will play a significant role" (Oseni \& Ahmad, 2015). This direction provides a suitable framework for the civil courts for the first time to explore every process of amicable dispute resolution before proceeding for court adjudication.

The main institution in Malaysia that uses this mechanism (court-annexed mediation) is the Kuala Lumpur Court Mediation Centre (KLCMC). The thing behind that is because the Practice Direction on Mediation issued in 2010 impliedly excludes other mediation centres like Malaysian Mediation Centre (MMC) from the court-annexed mediation program as it restricts the court-annexed mediation to only judge-led mediation.

\section{Ombudsman}

Ombudsman generally has wide investigative powers with few punitive powers. It is a highly independent, accessible and impartial form of review and investigation. The services of the Financial Mediation Bureau (FMB) in a way can be likened to the functions of an ombudsman because the bureau carries out some investigative role in addition to its mediating as well as adjudicating role.

The new Islamic Financial Services Act (IFSA) 2013 which came into operation on $30^{\text {th }}$ June 2013 is aimed at providing the regulation and supervision of Islamic financial institutions, payment systems and other relevant entities as well as the oversight of the Islamic money market and Islamic foreign exchange market to promote financial stability and compliance with Sharīah and for other related, consequential or 
incidental matters including the resolution of its disputes. Its section 138 provides for the establishment of a Financial Ombudsman Scheme (FOS) which is to ensure effective and fair handling of complaints and for the quick resolution of disputes in connection with financial services or products. Financial service providers can therefore be a member of a Financial Ombudsman Scheme as approved and regulated under the Act for resolution of disputes referred to the financial ombudsman scheme. They must comply with any award granted under the said scheme.

Financial Ombudsman Scheme is defined under Section 133 as: "a scheme for the resolution of disputes between an eligible complainant and a financial service provider in respect of financial services or products". The Act further provides that regulations may be made by the Minister of Finance to require an Islamic bank to become a member of the FOS (Laidin, 2013). Such a bank must comply with all the regulations made by the Minister. It is to ensure that the scheme is fair, accessible and equally effective. Besides, it must provide documents or information as may be required for the resolution of disputes referred to the FOS; comply with any award granted under the FOS, including a direction that requires it to take such steps concerning a dispute. It is hoped that when this scheme is operationalised, it will employ the use of this mechanism (ombudsman) to its fullest.

\section{Mediation}

Mediation is a facilitative process through which disputing parties engage the assistance of an impartial third party, the mediator, who helps them arrive at a mutually agreed resolution to their dispute (Yaacob, 2012). Being an extension of the negotiation process, the mediator facilitates the arriving at a settlement by helping the disputants explore issues, needs and settlements options. The mediator has no authority to make decisions that are binding on the disputants but may only use certain procedures, techniques and skills to probed their motivation and concerns and help them settle without resorting to arbitration. The highest a mediator can do is to propose a settlement of the dispute. Even this must be at the request of, or with the consent of the parties (Yaacob, 2012). The Malaysian Mediation Centre (MMC) as a mediation institution, uses this mechanism in resolving the disputes between the parties of Islamic finance in Malaysia.

The mechanism is regulated by the Mediation Act 2012, which was brought into force on 1st August 2012. The Act was introduced with the aim of to promote and encourage mediation as a method of ADR and to facilitate the settlement of disputes in a fair and speedy manner. However, the Act has been widely seen as being merely a reproduction of existing procedural rules of certain professional mediation institutions, such as the Malaysian Mediation Centre and the Chartered Institute of Arbitrators which provide mediation services using their respective codes of ethics and rules, and therefore not entirely relevant. Primarily, stakeholders familiar with the mediation framework in Malaysia have long hoped for legislation to regulate the practice of mediation by mediators and the standardisation of competency 
requirements with minimum qualifications for mediators, whether or not through an accreditation system where authority is given the power to revoke or confer accreditation. The Act has not addressed these points. Most glaringly, whilst the Act preserves the voluntary process of mediation, it falls short of making mediation mandatory in certain appropriate instances.

There is also a new direction to the application of this mechanism to the resolution of Islamic finance disputes based on the recent AIAC Arbitration Rules which become effective in 2018. There is now a process of Mediation to Arbitration under its Rule 15 which states thus:

"If the Parties have referred their dispute to mediation under the AIAC Mediation Rules and they have failed to reach a settlement and/or the mediation has been terminated and thereafter decided to proceed to arbitration under the AIAC Arbitration Rules......"

This invariable means that it is possible to begin the dispute resolution process of a banking dispute with Mediation Mechanism and if the settlement was not reached, to complete it with an Arbitration mechanism.

\section{Conclusion}

The findings of this research reveal that there are indeed challenges faced by parties in the resolution of their disputes using the court process, which could be surmounted if carefully addressed. The adjudication system within the context of Islamic finance must be one which can authoritatively enforce the principles of Sharīah in dispute settlements involving Islamic financial transactions.

In an attempt to strengthen the court process, there is the need to train the civil court judges in the subject of Islamic finance so that they could sit and adjudicate on the cases as experts in the field and not merely as English trained judges. The training has to be rigorous as all the principles of fiqh muāmalät, fiqh, and usūl al-fiqh need to be studied. It will go a long way in saving the present situation where we have English trained judges with little or no background in Islamic finance, deciding disputes between Islamic banks and their customers.

Furthermore, there is the need to enhance the public awareness of the alternative dispute resolution mechanisms provided by various institutions in Malaysia as analysed in this article. It will help to increase its relevance in the industry and help achieve access to justice to disputing parties in the industry which will invariably translate to having stability and reliability in the Islamic banking and finance industry in Malaysia. An industry with a stable and strengthened dispute resolution mechanism will surely attract investors from all over the world, which will invariably mean more growth to the industry than is presently being experienced.

\section{References}

Ali, E. R. A. E. (2008). Constraints and opportunities in harmonisation of civil law and 
shariah in the islamic financial services industry. Malayan Law Journal, 4.

Ali, E. R. A. E., Oseni, U. A., \& Zubair, A. A.-Q. (2014). A SWOT analysis of the dispute resolution mechanisms in the islamic finance industry in Malaysia. In Contemporary Issues in Public, Human Rights and Islamic Law: Discussions and Perspectives (p. 612). Grosvenor House Publishing Limited.

Bälz, K. (2004). A murābaha transaction in an English court - The London high court of 13 th February 2002 in Islamic Investment Company of the Gulf (Bahamas) Ltd. V. Symphony Gems N.V. \& Ors. Islamic Law and Society, 11(1), 117-134. https://doi.org/10.1163/156851904772841435

Bustami, F. S. S., Ahmad, T. A., \& Kamal, M. H. M. (2010). Administration of Islamic Law in Malaysia: text and material (2nd ed.). LexisNexis.

Dahlan, N. K. (2018). Alternative Dispute Resolution for Islamic Finance in Malaysia. MATEC Web of Conferences, 150, 11-20. https://doi.org/10.1051/matecconf/201815005077

Halim, M. 'Afifi A. (2011). Enhancing the effectiveness of legal infrastructure: a study on legal issues and other challenges of Islamic banking and finance in Malaysia. The 8th International Conference on Islamic Economics and Finance.

Hamzah, W. A., \& Bulan, R. (2003). An introduction to the Malaysian legal system (5th ed.). Oxford Fajar Sdn. Bhd.

Hasan, Z. Bin, \& Asutay, M. (2011). An analysis of the courts' decisions on Islamic finance disputes. ISRA International Journal of Islamic Finance, 3(2), 41-71. https://ssrn.com/abstract=2089817

Ibrahim, A., \& Joned, A. (1995). The Malaysian legal system (2nd edn.) (2nd ed.). Dewan Bahasa dan Pustaka.

Laidin, M. A. (2013). IFSA 2013 prospects and future. International Conference on Commercial Law.

Leibowitz, D., \& Lester, C. (2002). Banking and finance disputes in ADR and commercial disputes (R. Caller (ed.)). Sweet \& Maxwell.

Leong, C. Y., \& Mann, J. C. F. (2012, October). The Asia-Pacific Arbitration Review 2013: Malaysia. Global Arbitration Review. https://globalarbitrationreview.com/benchmarking/the-asia-pacificarbitration-review-2013/1036720/malaysia

Malaysia, B. N. (2013). Financial Stability and Financial Report 2012 (Issue March). https://www.bnm.gov.my/files/publication/fsps/en/2012/fs2012_book.pdf

Miskam, S., \& Hamid, N. 'Adha A. (2011). Alternative dispute resolution in Islamic finance: from adversarial to non-adversarial justice. The Secon Asian Business and Management Conference.

Oseni, U. A., \& Ahmad, A. U. F. (2015). Dispute resolution in Islamic finance: A case analysis of Malaysia. In Ethics, governance and regulation in Islamic finance (Vol. 4, pp. 125-134). Bloomsbury Qatar Foundation. https://irevieu.com/wpcontent/uploads/2019/07/Islamic-Finance-Book_Volume_4.pdf\#page $=140$

Patail, A. G. (2007). Harmonisation of civil laws and sharīah: effective strategies for implementation. The 3rd International Conference on Harmonisation of Civil Laws 
and Sharī‘Ah.

Yaacob, H. H. (2012). Alternative dispute resolution (ADR): expanding options in local and cross border Islamic finance cases (3rd ed.). ISRA, International Shari'ah Research Academy for Islamic Finance.

Yiam, S. G. (2009). Court annexed mediation. In S. K. Rashid \& S. A. Idid (Eds.), Mediation \& arbitration in Asia Pacific: conference proceedings (1st ed., pp. 3742). IIUM Press. 